\title{
The Land of the Future: British Accounts of the USA at the Turn of the Nineteenth Century
}

David Seed

\section{(2) OpenEdition}

\section{Journals}

Electronic version

URL: https://journals.openedition.org/ejas/11536

DOI: 10.4000/ejas.11536

ISSN: 1991-9336

Publisher

European Association for American Studies

\section{Electronic reference}

David Seed, "The Land of the Future: British Accounts of the USA at the Turn of the Nineteenth Century", European journal of American studies [Online], 11-2 | 2016, document 1, Online since 11 August 2016, connection on 08 July 2021. URL: http://journals.openedition.org/ejas/11536 ; DOI: https://doi.org/10.4000/ejas. 11536

This text was automatically generated on 8 July 2021.

Creative Commons License 


\title{
The Land of the Future: British Accounts of the USA at the Turn of the Nineteenth Century
}

\author{
David Seed
}

1 Ever since the declaration of independence a sustained and complex dialogue took place between British and American writers. What Sylvia Strauss calls the "American Myth" of fresh, libertarian beginnings has persisted in debate throughout the nineteenth century (Strauss 66). Towards the end of that century anxieties began to grow in Britain over the emergence of the USA as a major economic power and as a player on the imperial world scene. At the turn of the nineteenth century an increasing number of works were published which Genevieve Abravanel has designated "Ameritopias," meaning "texts that imagine the future through America." These works for her represent an important part of a broader attempt to "rethink nation and empire." (Abravanel 25) Although Abravanel's coinage carries implications of utopian celebration which is by no means a standard feature of turn-of-the-century writing, both commentators have rightly recognized that speculations on possible futures repeatedly included the USA in their scenarios as a major driving force for change. When the Scottish editor of the 1893 Baedeker guide to the USA, James Muirhead, attempted to sum up the national consciousness, he did so in terms of space and time, declaring that "it includes a sense of illimitable expansion and possibility; an almost childlike confidence in human ability and fearlessness of both the present and the future" (274).

2 In what follows a range of writing will be examined from the late nineteenth and early twentieth century to see how their projections of the future are tied to a heightened awareness of the USA as an emerging economic and imperial power. The discussion will draw on Stephen Kern's study of the Western spatio-temporal culture between 1880 and 1918, particularly where he identifies two modes of imagining the future. The one is a matter of expectation, the other "active mode," as he calls it, pursues a future, using technology to bring about desired change (Kern 92-93). 


\section{Bulwer-Lytton}

3 In his 1871 novel The Coming Race, Edward Bulwer-Lytton was one of the first writers to articulate fears of Britain's imperial supremacy being usurped by the United States. As early as 1861 he reflected on the rise and fall of empires, worrying that Britain's might collapse under its sheer size. The divisions of the Civil War offered a welcome relief to Britain because otherwise "America would have hung over Europe like a gathering and destructive thunder-cloud" (Bulwer-Lytton, 1861). This sombre foreboding was to inform the conclusion to his novel.

4 The Coming Race opens when an American descends into a mine shaft and then falls through the Earth into a subterranean world of the future. His subsequent discussions with the Vril-ya, as these people are called, call into question the narrator's brash nationalism by showing how his people will be superseded by more rational, technologically advanced beings. When questioned about his "primeval" origins, the narrator indignantly replies that he "has the honour to belong to one of the most civilised nations of the earth" (Bulwer-Lytton 2005, 25). As Lillian Nayder has shown, Lytton displaces his imperial anxieties underground, depicting a possible future in a speculative space whose plausibility depends less on the credibility of life underground than on Lytton's extrapolation from the facts of his present era (212-221).

5 The simple fact of the narrator's fall carries negative implications for the evolutionary process, which was regularly figured as an ascent. Similarly, the humans underground are surprisingly tall, another suggestion of superiority. When he expounds the "present grandeur and prospective pre-eminence of that glorious American Republic" (Bulwer-Lytton 2005, 25), it becomes clear that Lytton is dramatizing a clash between the national optimism of the USA and a longer-term evolutionary possibility. ${ }^{i}$ The Vril-ya society seems to be a utopian realization of democracy in its absence of class and of competition, and therefore of "hazardous speculation." More importantly, they are united by their common faith in a "future state" (Bulwer-Lytton 2005, 51), although this future seems to offer the prospect of indefinitely extending their current well-being. As the novel progresses, the narrator gradually loses any doubts that they will displace himself and his race, hence his concluding direction to the reader to pay heed to his "forewarnings." The narrator attempts to stave off the imminence of racial defeat, reflecting: "the more I think of a people calmly developing... powers surpassing our most disciplined modes of force... the more devoutly I pray that ages may yet elapse before there emerge into sunlight our inevitable destroyers" (Bulwer-Lytton 2005, 144). Lytton's tortuous syntax mimes out a delay in his reluctant conclusion of inevitable change.

6 The first signs that the narrator receives of Vril-ya technology come with the "automata" he sees gliding around their dwellings and the devices which are operated by touch terminals. During a crisis when he attacks one of these beings, he is felled "as by an electric shock" (Bulwer-Lytton 2005, 20). Eventually the force is named as "Vril", which the narrator explains: "I should call it electricity, except that it comprehends in its manifold branches other forces of nature" (Bulwer-Lytton, 2005, 26). Bulwer-Lytton himself stated that he was trying to straddle the known and unknown: "I do not mean Vril for Mesmerism. But for electricity developed into uses only dimly guessed [suggesting] the one great fluid pervading all Nature" (Mitchell 230). In short, it was to 
suggest the force of forces. In his earlier works Lytton had repeatedly referred to electricity as a chain linking spirit and matter, and in the novel Vril figures as a versatile force enabling land, air and sea transport, public and domestic lighting. The American title of the novel foregrounded this force as the true protagonist: Vril, the Power of the Coming Race.Transmitted through a hand-held staff, it is a force whose application does not depend on physical strength and it that respect it symbolizes newfound gender equality, one of the main areas of anxiety in the novel. Its application disempowers the narrator, reducing him to a passive state of expectation of the future. Bulwer-Lytton's last unfinished novel, The Parisians (1873), continues the dialogue between present and future of The Coming Race by dramatizing the differences between European and American women and by having a character assert that America will "eclipse" Europe.

\section{Electrical Futures}

7 In Bulwer-Lytton's 1871 novel, Vril is dramatized through a series of events which disrupt the leisurely exposition of underground society: the immobilization of the narrator, the killing of a monster emerging from a lake, and so on. The sheer speed and ease of its application thus runs counter to the general reflective pace of the action and anticipates the prominence given to electricity in later writing. Not only associated with the future, it was mythologized as a preternatural force. The engineer A.E. Kennelly, for instance, described it in 1890 as "an Ariel before which time and place seem to vanish" (Kennelly 102). ii

8 Nunsowe Green's A Thousand Years Hence (1882) unusually introduces its description of a future world by describing a London debating society whose members discuss the likely developments in the near future. iii The volume shifts from abstract discussion into future retrospect as the narrator reflects on the last 1000 years, on a future where electricity has magically accelerated transport and opened up new possibilities for travel. By 2882, "the air is the ordinary medium of our daily locomotion" (Green 45) and an unlimited food supply. Electricity, like radium decades later, "opened to man a new range of power over the material universe" (108). Green's future links the elements of electrical energy and flight in a world where the USA has become assimilated into the world economy. "Old California" has become a key energy source and "Old Cincinnati" an expanded meat centre. A key development towards this global economy is the union between Britain and the USA "in the way of bridging the intermediate Atlantic," which is realized through massive ferry-boats resembling "swift-travelling cities" (121). This union immediately triggers a surge in transatlantic travel and an expansion of a shared economy, while Britain gradually loses its empire from failing to recognize the democratic current in political evolution.

9 Green's future world has transformed itself thanks to the discovery of electricity as a limitless power source. Similarly in W.S. Lach-Szyrma's Aleriel (1883), set on another planet at an unspecified time in the future, control of electricity has revolutionized transport and communication. ${ }^{\text {iv }}$ However, one of the most throughgoing electronic utopias was Scottish-born John Macnie's The Diothas or, A Far Look Ahead (1883), where the narrator falls asleep during a mesmeric experiment and awakes in the ninety-sixth century. As he gazes across the New York of the future ("Nuiore"), he registers the "unbroken lines of colonnade stretching toward the distant 
horizon" (Macnie 5). Apart from functioning as an emblem of order, the perspective line in this description implies the long vision of planners and even the perspective of time itself. We will encounter other instances of temporal perspectivism in this body of writing. In The Diothas the narrator's perceptions of space are supplemented by a character's account of how the late nineteenth century has been studied because it was "remarkable as a period of transition" (61) when many things seemed about to pass away. In this way the narrator develops a sense of his own present as history, as a transitional period giving way to a welter of inventions ranging from the "tachygraph" (a kind of dictaphone), color photography, and even a primitive form of cinema. Once again the overwhelming characteristic of this future society lies in its accelerated and varied means of communication.

10By the 1880s electricity had become a standard feature in the evocation of future worlds. In his pioneering study Domesticating Electricity, Graeme Gooday shows how during the following decade "dozens of speculations about the future electrical home and society" were published (137), triggered particularly by Edward Bellamy's Looking Backward (1888). ${ }^{v}$ In the latter, the narrator is told: "electricity, of course, takes the place of all fires and lighting" in the home (113), an important emphasis since the first widespread applications of electricity took place in the public not domestic sphere. Bellamy does not even give a token explanation of this transformation, instead using electricity as the symbolic sign of social well-being. Thus Kenneth Folingsby's Meda (1891) describes the world of 5575, when the discovery of how to store electricity has been applied in rail transport, countless domestic machines, the telephone, and even a form of television. ${ }^{\text {vi }}$ The narrator, visiting from the year 1888, learns that a key event in subsequent history yet again has been the union between Britain and the USA. ${ }^{\text {vii }}$ Folingsby's narrator is left in no doubt about his evolutionary status when he is addressed as "specimen" by the inhabitants of the future world. Macnie's narrator suffers an even more explicit humiliation. His unqualified admiration for the "magnificent race" he encounters leads him to imagine that he has been pushed backwards down the evolutionary scale: "I felt within me that I belonged to the dark ages of the past" (Macnie 17). Thisfuture world has become a single state with a universal language based on English. In short, the globe has turned American.

11Among the successors to Looking Backward, H.W. Hillman's Looking Forward (1906), unusually includes a substantial American view of a transformed Britain. The role of electricity in imminent material progress is reflected in Hillman setting his account in 1912, in a future where every area of social life from the domestic to that of transport has already reaped the benefits of the new resource. Hillman's characters visit Britain, and as soon as they dock in Liverpool, they "see how rapidly England had taken up the various applications of electricity" (123). Everywhere they go, they see electrical heating, buses and even aeroplanes, but the high spot of their tour comes with a visit to a huge factory complex run by an American industrialist. The easy combination of US know-how and British industrial enterprise contrasts starkly with some UK accounts of the economic threat from across the Atlantic, as we shall see. For Hillman, however, the influence reflects a simple lesson in technology: "the merchants of England were very quick to learn of the great results secured by the merchants in America about the year 1906" (132-133). 


\section{Anglo-American Union}

12Where Hillman blithely assumes that a unification of British and American technology can take place without any political problems, most writers on AngloAmerican union either present it as an ultimate desired goal or focus on the difficulties of bringing it about. One of the most positive assertions of joint progress was made only one year after The Coming Race by the explorer William Winwood Reade in his "universal" history, The Martyrdom of Man (1872), which was to have its influence on H.G. Wells. viii Reade's premise was that America was both the happiest and "most civilized nation on earth" (510-511). That being the case, the USA becomes the measure of progress and "that England may become as prosperous as America, it must be placed under American conditions" (511). Reade does not present this as a warning so much as a statement of necessity and underpins his assertion with two technological necessities: the "discovery of a motive force which will take the place of steam" and the "invention of aerial locomotion" (513). For subsequent writers the force in question was clearly electricity.

13Reade's utopian links between flight and a technology to replace steam were embedded in Percy Greg's 1880 novel Across the Zodiac, which uses an elaborate frame for its account of a future world. The primary narrator is a British traveler touring Fenimore Cooper's America in 1874. He meets and befriends a former Confederate officer who recounts how in 1865 he discovered a container in the ruins of a flying vessel which at first resembled a "brilliant star" (Greg 1880, I.13). Within this container he finds the record of a flight to Mars made in the 1820s by a scientist who has discovered a force he has named "apergy." Society on Mars represents a possible future containing a whole series of technological innovations like electric ploughs and carriages, a device called a "voice-writer," and factories with minimal operatives. The streets are even more magnificent than "the finest and latest-built American cities" (Greg, 1880, I.199). The multiple framing of the narrative within American history and the use of the USA as a reference point for progress suppress our consciousness of Greg's own nationality. Indeed a character in his 1878 debate volume, The Devil's Advocate, declares that American democracy was the "most certain irresistibly growing and controlling tendency of the age" (Greg 1878, II.323). In Greg's novel time on Mars is measured from a single event: the "union of all races and nations in a single State" (Greg 1880, I.125) which took place thousands of years in their past. Mars thus functions as speculative location for technological change offset by the presence on the red planet of autocracy and conflict. ${ }^{\text {ix }}$

14Size becomes an index of evolutionary superiority in Harold Brydges' A Fortnight in Heaven (1886), which describes the voyage to Jupiter of an English sea-captain's "spiritual double." Here he finds gigantic humans populating an alternative futuristic America. One of the first spectacles to confront him is a new Chicago, transformed into a city of crystal. The main force behind this transformation is electricity, powering "electric pedestrianism" (through a kind of accelerated bicycle) and "aerial ships." Despite its labored humor in parodying a form of socialism, A Fortnight clearly projects a conviction that America's future lies in its technology. The traveler reflects that "such an America as he imagined may result on Earth after another century of progress" (17). Once the apparent shock of novelty has worn off a process of recognition takes place as the captain realizes that the "wonders" before him were 
either "looming in the near future" or already being projected at the time of his flight, dated at 1886 (46). Thus the trajectory of the narrative temporarily estranges the captain from his present so that he arrives at a new understanding of the signs of an imminent future.

15Brydges made the American theme explicit in his 1888 portrait Uncle Sam at Home, which concludes its national sketches with a consideration of Manifest Destiny. Dismissing the bombast of politicians, he nevertheless insists that "it is unquestionably the "manifest destiny" of America to leave all the nations of the world far behind." Brydges looked forward confidently to the "ultimate dominance of the English race" (Brydges 1888, 236), by which he meant a union between the USA and Britain. In this belief he was explicitly following the Anglo-Saxonism of the American political philosopher John Fiske, who saw it as the mission of both nations acting together to establish a "higher civilization" in the world. Rhetorically he veered between asserting the joint destiny of the "English race" to rule the world and celebrating American supremacy. In the conclusion to his American Political Ideas (1885) he grandly predicted that "in the United States a century hence we shall... doubtless have a political aggregation immeasurably surpassing in power and in dimensions any empire that has as yet existed" (Fiske 181). With encouragement from T.H. Huxley in Britain, Fiske presented the nation as an evolving racial aggregate where the two nations would work together to fulfill their destiny, although in the passage above one partner is conspicuous by his absence. ${ }^{\mathrm{x}}$

16By the 1890s many writers had come to accept that the destinies of the USA and Britain were intertwined. The journalist and editor Robert Barr lived out this connection, residing variously in Canada, the USA, and then Britain. Two of his short stories offer cautionary tales about the failure of cooperation between the two countries and the unforeseen dangers which might arise from collaboration. "The Doom of London" (1892) is narrated by a clerk in a chemical company who draws parallels with the fate of Pompeii to attack the "feeling of national conceit" (70) characterizing his era. He describes how an American inventor approaches his boss with a "health machine" that produces oxygen. Sir John dismisses his visitor and soon afterwards falls victim like the rest of London to that city's smog. As the latter reaches critical density, the narrator tries to find a train in Cannon Street station and witnesses a spectacle of deadly futility: "The electric lights burned fitfully. This platform was crowded with men, who fought each other like demons, apparently for no reason, because the train was already packed as full as it could hold. Hundreds were dead under foot, and every now and then a blast of foul air came along the tunnel, whereupon hundreds more would relax their grips and succumb" (77). Barr austerely refuses any consolatory ending, with the narrator narrowly surviving a subsequent train crash while the deaths continue to mount up. The moral is clear. Conservatism, not destiny, decides the fate of the metropolis. The action is set in the very near future and time is speeded up so that the narrator actually witnesses mass deaths, which ultimately result from the expansion of London during the nineteenth century, described as if through first-person reportage.

$17 B$ arr returned more problematically to the combination of American enterprise and British capital in his 1900 story "Within an Ace of the End of the World," where a young American develops a form of nitrogen extraction which revolutionizes food production. Herbert Bonsel has worked with Edison and so appears to have impeccable 
scientific credentials. Then he strikes lucky in finding a rich aristocratic backer in Britain and together they form the Great Food Corporation. So far so good. But when they start production a lone critic warns against the dangers of nitrogen depletion, a warning that falls on deaf ears. Then a worldwide series of conflagrations take place which destroy the world's cities and most of the population. Decades before the spectacle of nuclear explosions came to haunt our imagination, Barr describes a surreal transformation of New York: "the city itself presented a remarkable appearance. It was one conglomerate mass of gray-toned, semi-opaque glass... The outlines of its principal thoroughfares were still fairly indicated, although the melting buildings had flowed into the streets like lava, partly obliterating them" (Barr 2000, 456). The national ironies of his earlier story have now given way to a concern with ecological balance. The narrative describes a major catastrophe which Barr tries to rationalize awkwardly as a kind of ethnic and pacifist cleansing: "the race which now inhabits the earth is one that includes no savages and no war lords" (457). What is most striking about both of Barr's stories, however, is the disparity between the scale of events and the brevity of each narrative. ${ }^{\mathrm{xi}}$ The effect is as if he has taken different hypothetical scenarios, both emerging from late nineteenth-century technological experimentation, and then accelerated their development so that the reader is left in no doubt at all about consequences. Essentially each story revolves around specific events which disrupt the flow, and therefore the grand narrative of social evolution. The one reflects a failure of what Stephen Kern has called the "active mode" of engaging with the future, the second the misapplication of technology.

18Where Barr focuses on technology, Arthur Bennett uses a Swiftian parable of empire, The Dream of an Englishman (1893), to speculate on the political future. John Bull is getting old and having increasing difficulties managing his colonial "children," Africa, India, and others. The imperial federation he forms is reinvigorated by the younger Brother Jonathan and concludes on a climactic note: "And some of the boldest of 'the coming race' were looking out upon the stars, and wondering if there were worlds to conquer there. And the federations which their poets sang of, now, were federations of the solar system" (189-190). Bennett is explicitly referencing BulwerLytton here, with the difference that the Vril-ya are "othered" as a threatening superior race, whereas here the present shades easily into a future where AngloAmerican hegemony is unquestioned. For Bennett the imperial gaze presumes a desire, indeed a right, to conquer.

\section{W.T. Stead, Kipling and the Anglo-Saxon Race}

19The journalist and editor W.T. Stead had a complex attitude to the USA, by no means uniformly favourable. In the 1890s he wrote extensively on municipal reform,

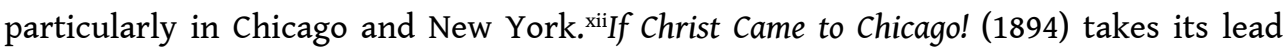
from James Russell Lowell's poem "A Parable" to apply the notion of a "Citizen Christ" to the problems of homelessness, electoral abuse and monopolies in the life of that city. As Stead declares, "I came to America to see what Mr. Carnegie described as the Triumph of Democracy. I found instead the Evolution of Plutocracy" (349). His allusion here is to Andrew Carnegie's Triumphant Democracy (1886), which presents an extended celebration of the material prosperity of the USA. Carnegie makes his position clear when he declares that "in population, in wealth, in annual savings, and in public credit; 
in freedom from debt, in agriculture, and in manufactures, America already leads the civilized world" (Carnegie 1886, 1). Carnegie deploys a whole range of statistics to demonstrate the staggering growth in national production, extrapolating the process and articulating freedom in market terms as the "march of the world towards the free and unrestricted interchange of commodities" (195). Despite this universal progress, Carnegie attributes the prosperity of the USA to race: "fortunately for the American people they are essentially British" (16). Indeed the explicit aim of his book is to provide for British readers overwhelming evidence for the community of interests between the USA and Britain. In contrast with Carnegie's celebration of statistics, Stead uses Christianity to give him an external perspective on the abuses he witnessed in Chicago, which he documents in considerable detail. Where Carnegie extrapolates his statistics into an ever more prosperous future, Stead focuses on the material conditions of the present. Even here, however, his ambivalence over the USA is reflected in a major change of tone towards the end of his volume when he moves away from urban abuses and waxes enthusiastic about the civic revival which he sees as taking place there which transforms Chicago into the "ideal city of the world" (Stead 1894, 410).

20In his preface to the British edition of If Christ Came to Chicago! Stead claims the symbolism of fusing the cultures of America and Britain: "this volume, written in Chicago, printed in Edinburgh, and published in London is typical of the unity of the English-speaking world" (iv). Stead promoted the cause of Anglo-American union in the 1890 launch issue of his journal the Review of Reviews, where his appeal "To All EnglishSpeaking Folk" asserted that "among all the agencies for the shaping of the future of the human race, none seem so potent now and still more hereafter as the Englishspeaking man. Already he begins to dominate the world. The Empire and the Republic comprise within their limits almost all the territory that remains empty for the overflow of the world" (Stead 1890,15). Stead combined imperial optimism with a secular faith in progress. He confidently rides the crest of a perceived direction to evolution celebrated in this appeal which combines the old and the new. Thus he insists that "to save the British Empire we must largely Americanize its constitution" (16). There is a clear warning here against narrow nationalism which is bolstered by an evangelical fervour in the essay. Stead insists that empire forms part of a divine mission, declaring: "the English-speaking race is one of the chief of God's chosen agents for executing improvements in mankind" (17). He went on to give an even higher profile to the USA.

21Stead's conviction that the future lay with America was further elaborated in his novel From the Old World to the New, which made up the Christmas 1892 issue of his journal. Built on a conventional romance narrative, the novel describes how a group of tourists visit the Chicago World's Fair. The relation of the USA to Britain is debated by them before they set off on their travels and Stead sets up a contrast between British conservatism and antiquity against American youthfulness and inventiveness. The novel opens on Christmas Eve, symbolically suggestive of a new era. The aerial view of the fair together with the novel's sub-title-A Christmas Story of Chicago Exhibitionwhich appeared on the cover of the first edition tacitly invest the fair with a spiritual dimension which feeds into the narrative. The protagonists are in effect time travelers moving out of the past into the future, the old into the new, out of the world of tradition into technological inventiveness. Indeed the tourists' arrival in New York takes on a visionary dimension. To one character, "the lights of New York, through the 
soft twilight of June, seemed a mystic hieroglyph, in which he read a prophecy of things to come" (54). It is not so much the details in the image as its means of visibility which is being stressed here. Electricity is power source of the future.

22The illustrations which punctuate the novel serially reinforce the transitions experienced by the travelers. Picturesque images of Chester and Stratford give way to a new emphasis on technology. Thus the first illustration of New York shows the elevated railroad; then we see the luxury of the train to Chicago; finally, the visual climax to the novel comes with a two-page spread giving a bird's eye view of the forty-acre exhibition site. After this arrival, the novel shifts into a discursive guide to the fair and the boundary of its fiction blurs into a series of advertisements for American transport. Although the fair was called the World's Columbian Exhibition in honor of Columbus' landing in America, its exhibits were directed towards the imminent future, where domestic and industrial life would be revolutionized by its new inventions.

23From the old World is not only a romance and travelogue. It also contains extended debates over the cultural contrasts experienced by the travelers. Even before they set out, they engage in heated arguments over the relation of America to Britain, its supposed barbarism and lack of history. But then a character enters the narrative who is clearly designed to be Stead's mouthpiece. Jack Compton is an entrepreneur defined by his potential energy rather than by his past. ${ }^{x i i}$ Appropriately in mid-ocean, since he is convinced that a new era is about to dawn, he points out the real importance of Stead's narrative: "what is at stake at Chicago is the headship of the English-speaking world" (38). He warns his listeners that Britain may lose this by default because they are so distracted by Irish affairs.

24Stead returned to the relation between the two nations in his best-known work of political commentary, The Americanisation of the World (1902). Here he makes no bones about his position, asserting that "the advent of the United States of America as the greatest of world-powers is the greatest political, social, and commercial phenomenon of our times" (5). The dilemma faced by Britain is how to participate in this surge of modernity and Stead calls for an acceptance of its inevitable loss of imperial supremacy by forming a "race union" with the USA. There is no issue of power involved since both nations share the same "family," a standard metaphor within the discourse of AngloSaxonism in this period. Stead returns to the fears that were preoccupying BulwerLytton and deflects them on to the working of the evolutionary process: "the Briton, instead of chafing against this inevitable supersession, should cheerfully acquiesce in the decree of Destiny, and stand in betimes with the conquering American" (9). Indeed, the cover to Stead's book shows americanization as a fait accompli with the stars and stripes waving over the globe. Glancing probably at the United States' appropriation of Spain's former colonies, Stead speculates on the sources of American energy and finally attributes it to the flood of immigrants, which produces a "composite race." Stead's notion of race is shifts according to his local argument and is basically drawn on to bolster his faith in Anglo-American world supremacy. ${ }^{\text {xiv }}$ Once again a key technological development becomes the hallmark of modernity: "The Americans have done with electricity what the British did with steam" (137). 


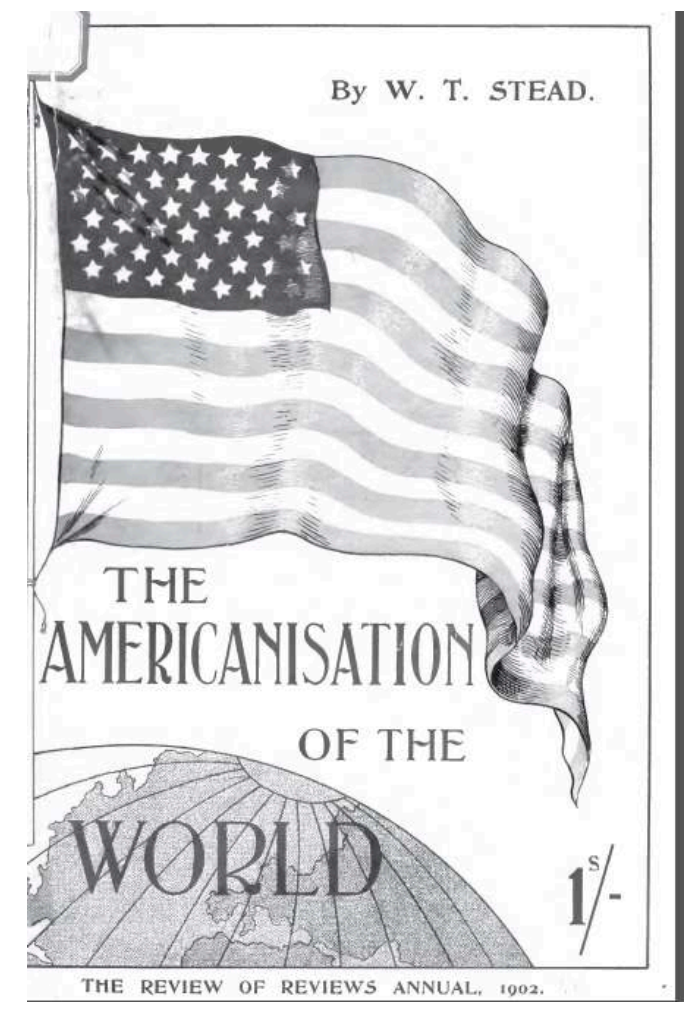

W.T. Stead, The Americanisation of the World (1902)

25Stead acknowledges with a citation one of his source texts for this piece of polemic. In 1893 the Scottish-American industrialist Andrew Carnegie joined the debate in an essay entitled "A Look Ahead," where he declared the need for a "race confederation" between the two countries. This was hardly a disinterested proposal because it would have opened up enormous markets, but Carnegie poses the case, like Stead, as an evolutionary inevitability: "the only course for Britain seems to be reunion with her giant child, or sure decline to secondary place, and then to comparative insignificance in the future annals of the English-speaking race" (Carnegie 1893, 697). Again like Stead, he visualizes Anglo-Saxon supremacy through suppressing imperial or racial rivals. There are, however, two contrasting strands to Carnegie's prediction. Against the entropic decline of an isolationist Britain he foresees a millenarian future where Anglo-American naval fleets would rule the world and usher in a period of universal peace. In answer to the objection that this is utopian, Carnegie can only insist: "I see it with the eye of faith" (710). When Stead read Carnegie's piece he wrote to congratulate a kindred spirit, declaring: "I am delighted to see how vigorously you are pushing forward the great idea of our race." ${ }^{\mathrm{xv}}$

26The cause of union was actively pursued by the novelist Walter Besant, who in his 1896 article, "The Future of the Anglo-Saxon Race," spelled out the many cultural links between the USA and Britain. The future for him lay with America which was "destined to become far more glorious in the future" (134), whereas the growth of republicanism in the British colonies could only result in transformation at the very least and perhaps even the loss of empire. For Besant only two possible futures presented themselves: one of strife between the two powers or a rational pooling of interests. The most profitable way forward would be for the countries to form a "great federation of our race" (143), 
which would stand as an example to the world. This cause was not only a matter of political conviction for Besant. In 1900 he founded the Atlantic Union club, which was dedicated to improving relations between Britain and the USA and whose membership included Arthur Conan Doyle. ${ }^{\text {xvi }}$ In 1901 Besant more forthrightly proclaimed that the question facing the new century was whether government by the people was possible. The answer was unambiguous: "it is to America," he declared, "and to America alone, that we must look" (Besant 1901, 21). And so yet again America functions if not as a direct example, then as an instructive lens through which the future can be read.

27Stead's vision of an Anglo-American future was ultimately shared by a 1906 account of technological innovation by "Tems Dyvirta" with the Wellsian title "London's Transformation. A Suggestive Sketch of Days to Come." Here Cornelius Tush, an American financier, develops an elaborate scheme to divert the Thames (hence the author's pseudonym) and build over the river bed in London. When Tush stands on Westminster Bridge to contemplate the transformed city, his perception is anything but Wordsworthian. Where the poet found an emblem of order in the city, Tush sees an urban utopia which bears testimony to American enterprise: "What he now looked down upon was an extensive view of the finest street in all the world [the Thames bed has become "Libertia Street"] On either hand rise magnificent new buildings of imposing architecture" ("Tems Dyvirta" 339).xvii Shops and business houses have their entrances on the ground floor, while walkways run along the roofs and across footbridges. Horse-drawn traffic, as befits an anachronism, is segregated into a separate road and running down the centre of the new city is an "avenue of fresh green trees, bordering a gravel walk" ("Tems Dyvirta" 339). The perspective line supplied by this avenue draws Tush's eye into the depths of the scene and into vistas of prosperity.

28The only complication lies in the Londoners. Tush's attitude towards the British veers round to overt hostility when they resist his take-over. Coincidentally at this point Tush runs successfully for president on an anti-British packet and economic colonization rapidly shifts into overt warfare. The Americans win a major naval battle thanks in part to their new "huge submarine battleship ("Tems Dyvirta" 366) and they then send forces to invade England. Here the tide of the war begins to turn against them, despite the advantages of American military know-how. The banks of the New Thames offer such efficient fortifications that the Americans fail to subdue the metropolis. Furious at this defeat, the self-styled "emperor" of America suffers a seizure and dies, being succeeded by his daughter who immediately calls for an armistice and then proceeds to marry the British heir to the throne. In her commentary on this sketch Genevieve Abravanel argues that the "utopian aim of the story is to dream of a geopolitics where British Power remains frozen in a static vision of unending progress; a vision only made possible by the assimilation of the burgeoning world power across the Atlantic" (Abravanel, 28). It's not clear how progress can be static and the end result of the dynastic marriage is better described as a merger producing "unity, peace and concord" ("Tems Dyvirta" 368). "London's Transformation" describes serious conflict, often fatal, between the two countries and the marriage symbolically unites younger more forward-looking members of each regime. Indeed one meaning to the sketch's title could be the change brought about in the national consciousness by events. The narrative accelerates change into a rapid montage of visual spectacles-the use of the descriptive present in the new view from Westminster Bridge is revealing. The accounts of the naval battle and the siege of 
London read like futuristic news accounts, culminating in an idealized combination of British imperial strength and American commercial and military inventiveness.

29A similar but more drawn-out trajectory is followed in Louis Tracy's 1896 novel of the, The Final War, whose action takes place in 1898, which dramatizes a clash between national futures. France and Germany attack Britain and are then joined by Russia. At this point the ties of kinship overwhelm American neutrality and the USA-"the western branch of the great Saxon race" (Tracy 264)-throws in its lot with Britain. The world war finally concludes with victory by the two national instruments of the Divine Will, which issue a joint proclamation outlawing armies and munitions (except in Britain or the USA). It has been the war to end war and, just in case the reader should miss this point, Tracy points the concluding chapter to point the moral in no uncertain terms: "this, then, is the mission of the Saxon Race-slowly but surely to map itself over the earth, to absorb the nations, to bring to pass that wonderful dream of a world united in a single family and speaking a common speech" (462). The assertion of kinship, initially used to rationalize American entry into the war, is here given global extension as the pacifist millennium dawns and here a paradox emerges in Tracy's novel. In his preface he describes it as a "story of adventure," whose specifics are extrapolated from the imperial politics of the period. However, the culmination to the action is an indefinite period of peace where such war has become an anachronism. Within the new dispensation a tale of adventure would be a historical document and Tracy's imminent future already a thing of the past.

30Rudyard Kipling similarly believed fervently in an imperial destiny shared by Britain and the USA. He famously wrote his poem "The White Man's Burden," originally sub-titled "The United States and the Philippine Islands, 1899," as a call to the United States to take up their share of imperial responsibilities, whose success would be judged by posterity. Judith Plotz has shown that Kipling's writing assume an Anglo-American world hegemony and argues that Kipling never lost a conviction that the USA was "potentially estimable if an imperial partner." In 1889, for instance, he envisaged the "Man of the Future" as "Anglo-American-German-Jew," which prioritizes the first two race labels (Plotz 40, 47).xviii

31Despite Kipling's faith in a shared imperial mission, the second of his futuristic tales shows real ambivalence about the future he is evoking. Both "With the Night Mail" (1905) and "As Easy as A.B.C." (1912) present a post-national future ruled by a technocratic elite where air power is paramount. In the first an Aerial Board of Control, is described as the "semi-elected, semi-nominated body [which] controls this planet" (Kipling 1951, 138), a body whose slogan is "Transportation is Civilization." In the later story transportation is also power, however, because when Northern Illinois withdraws from the global electronic network, airships hover over Chicago temporarily blinding and deafening the rebels with electronic weapons. Electricity is clearly the key resource in this global economy, although Kipling's story is oddly ambivalent about the future, perhaps because written against the background of impending war. The key imagistic contrast falls between the darkness of the landscape, as if the local population has reverted to barbarism, and the lights from the airships signifying the new technology. Kipling limits the chronology of his story to an opposition between now and then, where all periods of the past blur together into the "days of the Crowds and the Plague" (Kipling 1952, 11). It is as if the passage of time has moved into an extended millenarian present where time itself has become an anachronism. Thus, a character 
describes how Chicago "used to be in the forefront of what they used to call "progress" (Kipling 1952, 4). The ambiguities of the story are complex because, as Angus Wilson has argued, the narrative starts at a moment of breakdown and all the officials seem disillusioned with their system (Wilson 331). Kipling seems to evoke a federal future which includes Britain and the USA, but singles out America as an oddly old-fashioned source of dissidence.

32At the turn of the century works proposing a union between the USA and Britain sometimes include conflict, if only as a consequence to be avoided. Stead's term "americanization" suggests a far more gradual cultural influence, quite distinct from its usage within the USA where it denoted the process of assimilating new immigrants. The Scots-Canadian journalist Frederick McKenzie deployed the terminology of empire in The American Invaders (1901), whose title implies that Britain is under attack. His real target, however, is British commercial complacency. McKenzie presents a whole detailed catalogue of instances to show that in every field of life American commerce is superseding that of the British because of their out-dated practices and laws. The first illustration to his volume, entitled "Triumphant March of American Products" shows Uncle Sam marching confidently into the left foreground, leading a whole train of American goods while a bewildered John Bull, presumably thrown off his feet by the sheer scale of this activity, gazes on helplessly. ${ }^{x i x}$ The illustration graphically represents a quasi-military occupation taking place without any opposition. Although McKenzie presents his volume as a wake-up call, insisting that "the future still lies before England if England will but have it" (10), the sheer number of his instances pull against this dutiful expression of hope. Indeed, he concludes the volume by admitting that "the most unpromising factor in the situation to-day is the way Americans are preparing for the trades of tomorrow" (155). And so it seems that after all the future lies with America because it has become woven into their commercial planning. 


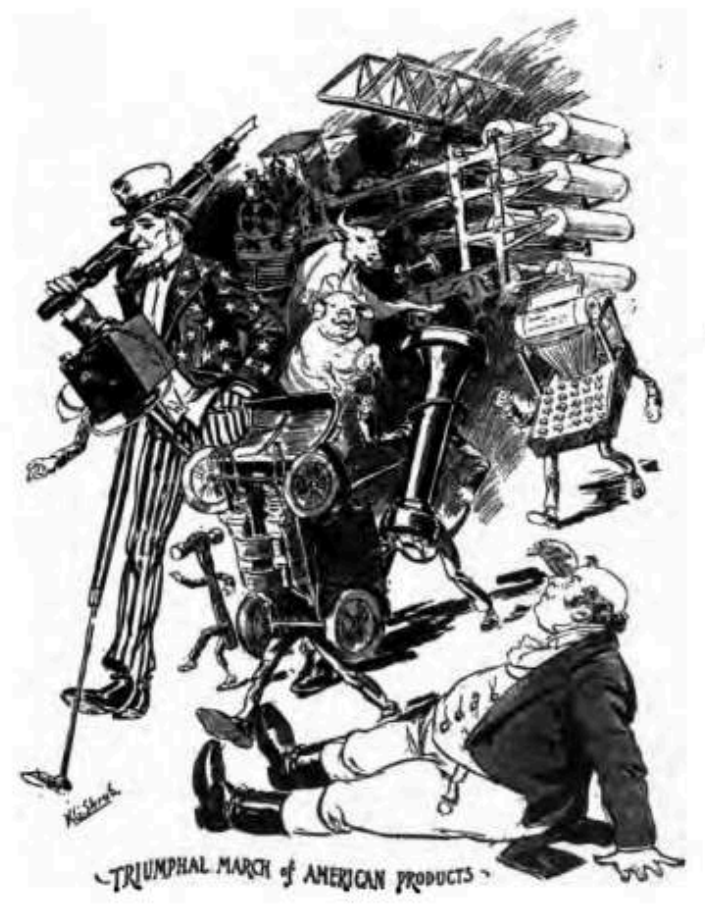

'Triumphal March of American Products'

\section{Wells and the New Order}

33It is a sign of the times that H.G. Wells's lecture to the Royal Institution in 1902, "The Discovery of the Future," should analyze the concern central to the writings examined here and also that it should take as its premise his assertion that "we are in the beginning of the greatest change that humanity has ever undergone" (Wells 1989, 35). Wells carefully stressed that he meant a whole process rather than a single epochal event, but cultural change for him required a change in mentality away from retrospectively measuring the present against the past to a new active capacity to speculate inductively on the future. Although Wells did not visit the USA until 1906, he already included it in his 1902 volume on current technological progress, Anticipations. Here he speculates on a "great synthesis of the English-speaking peoples" (Wells 1902, 260), foresees that America's ascendancy in industrial output may lead to imperial supremacy, and even considers a joint Anglo-American flag. ${ }^{\mathrm{xx}}$

34The dominant impression he recorded from his 1906 visit in a volume revealingly entitled The Future in America was one of boundless technological growth and with that an accelerated tempo of life. ${ }^{x x i}$ As the long avenues of New York open up perspectives on the future for Wells, he visualizes utopian change through a series of cinematic dissolves:

One has a vision of bright electrical subways, replacing the filth-diffusing railways of to-day, of clean, clear pavements free altogether from the fly-prolific filth of horses coming almost, as it were, of their own accord beneath the feet of a population that no longer expectorates at all; of grimy stone and peeling paint 
giving way everywhere to white marble and spotless surfaces, and a shining order, of everything wider, taller, cleaner, better [.] (Wells 1906, 43)

These are not directly visual images so much as glimpses of a virtual future America seen through the specifics of contemporary actuality.

36 Before Wells sailed to the USA, he had already visited that country through the works of commentators like Stead and Edgar Saltus, whose 1905 article "New York from the Flatiron" is cited in The Future immediately before the passage quoted above. Saltus uses the new vantage point offered by the Flatiron Building to engage in futuristic speculation. His text glosses a series of aerial panoramas of New York, where Broadway, Fifth Avenue and other routes draw the observer's gaze into the deep background of each image, offering perspectives on the future. The illustrations supply concrete examples of urban technological achievement where the dwarfed human figures down at street level hint at the constant activity of the city.Saltus stresses process in the "ceaseless skyscrapers ceaselessly going up" and makes his temporal perspective explicit when he declares that the Flatiron's "front is lifted to the future" (Saltus, 1905, $382-3,390)$. Time, however, is also measure vertically as new buildings rise above the old and even new beings will emerge: "In the mounting wonders of the city to be, humanity will mount also.... You get a vision of that in the significant sunsets and prophetic dawns" (390). Wells borrowed this rhetoric of epochal emergence in The Future in America and explained how his heightened sense of change desubstantialized the sights before him: "there are times indeed when it makes life seem so transparent and flimsy, seem so dissolving, so passing on to an equally transitory series of consequences" (Wells 1906, 4). Robert Frankel makes the important point that, despite his title, Wells was consciously not engaging in prophecy in this work, but rather scrutinizing the American present to extrapolate its cultural direction (Frankel 85). 


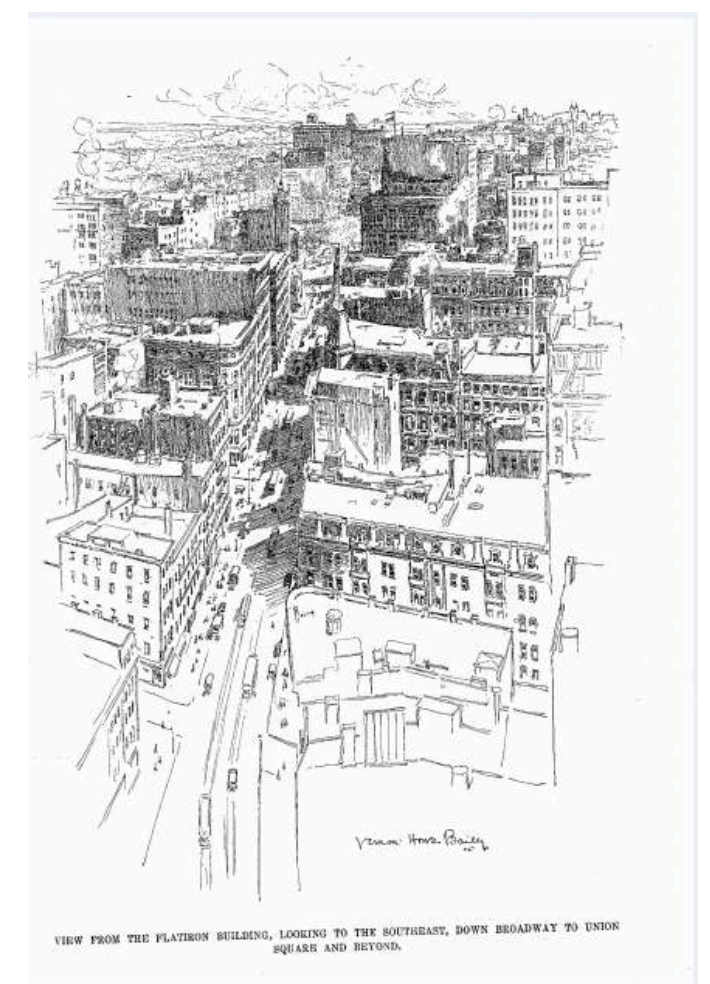

'View from the Flatiron Building, looking to the southeast, down Broadway to Union Square and beyond.'

37In 1906 Wells was already speculating on a possible union between Britain and America, and increasingly expressed the hope that the USA would initiate a new world order after the disruptions of the First World War. ${ }^{\text {xxii }}$ In The Shape of Things to Come (1933), elaborately edited as the "dream book" of a Wellsian speculator named Philip Raven, the USA spearheads the world's move away from old-style national interests. Wells introduces a utopian presidential figure called "Roosevelt II," whose book Looking Forward becomes a best-seller in Europe and which marks a step towards the formation of a world state. However, Wells's hopes for such a synthesis are undermined by the increasing hiatuses and final disorder of Raven's manuscript.

\section{Skyscrapers Magical and Otherwise: James and Chesterton}

380ne of the most dramatic sights confronting British travelers to America was the New York skyline, which impressed Wells, although he gave more symbolic importance to the Brooklyn Bridge. For the novelist Arnold Bennett on his 1911 visit, the night scene of the skyscrapers was "stupendous, and resembles some enchanted city of the next world rather than of this" (Bennett 1912, 38). Skyscrapers, in short, became the visual tokens of American enterprise. Against such a perception, we turn here to one account which refused such symbolism and another which ironically revised it.

39 For Henry James the very signs of American modernity are summed up as a "Frankenstein monster," his choice of phrase in an 1898 essay where he comments on 
the post office, newspaper and railway (James 1984, 664). Where other writers would see these as the positive signs of an emerging future, James links them with the classic narrative of unforeseen destruction. In The American Scene (1907) he elaborated on this figure to express his bewilderment at the transformation of his native country. New York was the test case for most visitors because it was the usual port of arrival and because Manhattan presented the most startling spectacle of technological development. James recoiled from what he saw because throughout The American Scene he was concerned with the past, how the USA related to its own history and to his own personal memories. Extrapolating from the Brooklyn Bridge, he has a nightmare vision of an expanding mechanism running under its own impetus: "The appearance of the bold lacing-together, across the waters, of the scattered members of the monstrous organism-lacing as by the ceaseless play of an enormous system of steam-shuttles or electric bobbins (I scarce know what to call them), commensurate in form with their infinite work-does perhaps more than anything else to give the pitch of the vision of energy." Unable to stabilize his impressions from the sheer scale of the sights before him, James struggles for expression and resorts to the metaphor of an enormous machine "working at high pressure, day and night, and subject, one apprehends with perhaps inconsistent gloom, to certain, to fantastic, to merciless multiplication" (James 1993, 418).

40Ultimately James is expressing a fantasy of displacement before this spectacle of industrial activity because he cannot imagine having any role within it. He does register a vision of the future, but far from celebrating progress, James glimpses a nightmarish process at work, endlessly expansive and apparently without any control. In that sense he is compelled to recognize an imminent future in America which he deploys his tortuous rhetoric to refuse. A similar strategy operates in his treatment of one of the visual hallmarks of American progress-the skyscrapers of New York. James reads them as brash advertisements for a system he distrusts: "they are impudently new and still more impudently "novel"-this in common with so many other terrible things in America" (James 1993, 419). His reaction is to diminish the skyscrapers to a pin cushion and to displace them from commerce on to the domestic. James justifies his strategy by insisting that the skyscrapers have no history, the ultimate condemnation in The American Scene. The past for him becomes the prime measure of quality and here a polemical edge enters James's descriptions. His denial of stature to the skyscrapers of course reflects his unease about the growing commercialism of America; but it also suggests that James was consciously writing against those visitors who were celebrating the spectacle of American innovation as an indication of its emerging future.

41In a more positive spirit, after he visited America in the 1920s, G.K. Chesterton recorded his amazement at the constant process of reconstruction which was going on in New York. Fascinated as he was by the sheer height of the skyscrapers, he nevertheless proposed scaffolding as the primary visual structure in that city, because it seemed to reflect so well what he called its "scene-shifting." Rather than focusing on either past or present, Chesterton explained how the city possessed a unique relation to time itself in its constant change: "ruins spring up so suddenly like mushrooms, which with us [Europeans] are the growth of age like mosses, that one half expects to see ivy climbing quickly up the broken walls as in the nightmare of the Time Machine, or in some incredibly accelerated cinema" (71). In his perception of a tempo to building and 
rebuilding, Chesterton is moving towards the machine rhythms evoked in later works like the 1936 film Modern Times.

\section{Coda: Aldous Huxley}

42The relation of the USA to the future was a complex subject for the writers discussed here, one characterized by ambivalence. While there is a general recognition of the startling growth in output and urbanization since the middle of the nineteenth century, British writers also expressed reservations about the possible consequences of this growth, especially in threatening Britain's economic and military superiority. This ambivalence was registered by Aldous Huxley, who recorded, after his first visit to America in 1926, his overwhelming impression that "change is accepted in America as the first and fundamental fact." When he visited the Hollywood studios Huxley saw models being made of the "architecture of the remote future" (Huxley 1930, 263), this could stand as a symbol of the direction being taken by American productive energy. Despite his intellectual recoil from the brash excesses of the culture, as Peter Conrad has argued, Huxley "thought of America as a laboratory in which the society of the future was being experimentally constructed" (Conrad 243). xxiii In the year following his visit Huxley sweepingly declared that "the future of America is the future of the World" (Huxley 2001, 185). In this essay, "The Outlook for American Culture" (1927), he not only makes a prediction of how the world might develop, but also offers a way of reading the present moment through the lens of time. "Literally everything in the present has some significance for the future," he declares (185). Huxley here follows the practice of earlier British visitors to the USA in reading the cultural landscape for signs of change and in attributing to America global leadership in that process. Huxley also addresses change to daily time in stressing the emerging problem of leisure. As machines replace human activity, the need grows for distractions to fill the time freed as a consequence and this was to become one of Huxley's main satirical themes in Brave New World. His perception of the USA as a future-directed culture did not prevent him from making Los Angeles the site for a post-nuclear recession into barbarism in his 1948 novel Ape and Essence.

\section{BIBLIOGRAPHY}

Abravanel, Genevieve. Americanizing Britain: The Rise of Modernism in the Age of the Entertainment Empire. New York: Oxford UP, 2012. Print.

Barr, Robert. "The Doom of London.” Science Fiction by Gaslight. A History and Anthology of Science Fiction in the Popular Magazines, 1891-1911. Ed Sam Moskowitz. Cleveland and New York: World Publishing, 1968. 69-78. Print.

---. "Within an Ace of the End of the World." The American 1890s: A Cultural Reader. Ed. Susan Harris Smith and Melanie Dawson. Durham NC: Duke UP, 2000. 447-457. Print. 
Barton, Samuel. The Battle of the Swash and the Capture of Canada. New York: Charles Dillingham, 1888. Print.

Baylen, Joseph O. “W.T. Stead and the Early Career of H.G. Wells, 1895-1911." Huntington Library Quarterly 38.I (1974): 53-79. Print.

Bell, Duncan. "Before the Democratic Peace: Racial Utopianism, Empire, and the Abolition of War.” European Journal of International Relations 10 (2014): 188-205. Print.

Bellamy, Edward. Looking Backward, 2000-1887. Ed. Alex MacDonald. Peterborough, Ont.: Broadview P, 2003. Print.

Bennett, Arnold. Your United States: Impressions of a First Visit. New York: Harper, 1912. Print. Bennett, Arthur. The Dream of an Englishman. London: Simkin, Marshall, Hamilton, Kent, 1893. Print.

Besant, Walter. “The Future of the Anglo-Saxon Race.” North American Review 163.477 (August 1896): 129-143. Print.

---. “The Atlantic Union.” The Forum (October 1900): 245-256. Web.

http://www.unz.org/Pub/Forum-1900oct-00245. Accessed October 22, 2015.

---. “The Burden of the Twentieth Century." North American Review 173.536 (July 1901): 9-21.

Brogan, Hugh. “Rudyard Kipling on America.” Journal of American Studies 7.I (1973): 31-46. Print.

"Brydges, Harold" [James Howard Bridge]. A Fortnight in Heaven: An Unconventional Romance . New York: Henry Holt, 1886. Print.

---. Uncle Sam at Home. New York: Henry Holt, 1888.

Bulwer-Lytton, Edward. "American Topics Abroad; Sir Bulwer Lytton on the Overgrowth of the United States." The New York Times (October 12, 1861). Web.

http://www.nytimes.com/1861/10/12/news/american-topics-abroad-sir-bulwer-lytton-on-theovergrowth-of-the-united-states.html. Accessed October 22, 2015.

---. Caxtoniana: A Series of Essays on Life, Literature, and Manners. New York: Harper, 1864. Print.

---. The Coming Race. Ed. David Seed. Middletown CT: Wesleyan U P, 2005. Print.

Carnegie, Andrew. Triumphant Democracy or, Fifty Years' March of the Republic. London: Sampson Low, 1886. Print.

---. “A Look Ahead.” North American Review 156 (1893): 685-710. Print.

Chesterton, G.K. What I Saw in America. London: Hodder and Stoughton, 1925. Print.

Conrad, Peter. Imagining America. New York: Avon, 1982. Print.

Fiske, John. American Political Ideas from the Standpoint of Universal History. Boston and New York: Houghton Mifflin, 1911. Print.

Folingsby, Kenneth. Meda: A Tale of the Future. London: British Library, 2011. Print.

Frankel, Robert. Observing America: The Commentary of British Visitors to the United States, 1890-1950. Madison WI: U of Wisconsin P, 2007. Print.

Gooday, Graeme. Domesticating Electricity: Technology, Uncertainty and Gender, 1880-1914.

London: Pickering and Chatto, 2008. Print. 
Green, Nunsowe. A Thousand Years Hence. London: Samson Low, Marston, Searle and Rivington, 1882. Print.

Greg, Percy. Across the Zodiac: The Story of a Wrecked Record. 2 vols. London: Truebner, 1880. Print.

---. The Devil's Advocate. 2 vols. London: Truebner, 1878. Print.

"Hermes" [Benjamin Lumley]. Another World; or, Fragments from the Star City of Montalluyah. London: Samuel Tinsley, 1873. Print.

Hillman, H.W. Looking Forward: The Phenomenal Progress of Electricity in 1912. Northampton MA: Valley View, 1906. Print.

Huxley, Aldous. Jesting Pilate. The Diary of a Journey. London: Chatto and Windus, 1930. Print.

---. Complete Essays. Volume III: 1930-1935. Ed. Robert S. Baker and James Sexton. Chicago: Ivan R. Dee, 2001. Print.

James, Henry. Literary Criticism. Ed. Leon Edel. New York: Library of America, 1984. Print.

---. Collected Travel Writings. Ed. Richard Howard. New York: Library of America, 1993. Print.

Kennelly, Arthur E. “Electricity in the Household.” Scribner's Monthly 7 (January 1890): 102-115. Print.

Kern, Stephen. The Culture of Time and Space, 1880-1918. Cambridge MA: Harvard UP, 1983. Print.

Kipling, Rudyard. Actions and Reactions. London: Macmillan, 1951. Print.

---. A Diversity of Creatures. London: Macmillan, 1952. Print.

McKenzie, Frederick A. The American Invaders. Their Plans, Tactics and Progress. New York: Street and Smith, 1901. Print.

Macnie, John [“Ismar Thiusen”]. The Diothas; or, A Far Look Ahead. New York: Putnam, 1883. Print.

Meckier, Jerome. “Aldous Huxley’s American Experience.” Aldous Huxley Annual 1 (October, 2001): 227-239. Print.

Mitchell, Leslie. Bulwer Lytton: The Rise and Fall of a Victorian Man of Letters. London and New York: Hambledon and London, 2003. Print.

Muirhead, James F. The Land of Contrasts: A Briton's View of his American Kin. Boston: Lamson Wolffe, 1898. Print.

Nayder, Lillian. "Bulwer Lytton and Imperial Gothic." The Subverting Vision of Bulwer Lytton: Bicentenary Reflections. Ed. A.C. Chistienson. Cranbury NJ: Associated UP, 2004. 212-221. Print.

Plotz, Judith. “Kipling's Very Special Relationship: Kipling in America, America in Kipling.” The Cambridge Companion to Rudyard Kipling. Ed. Howard J. Booth. Cambridge: Cambridge UP, 2001. 37-51. Print.

Reade, William Winwood. The Martyrdom of Man. London: Truebner, 1872. Print.

Saltus, Edgar. "New York from the Flatiron.” Muncie's Magazine 33.IV (July 1905): 381-390. Print. Stead, W.T. “To All English-Speaking Folk.” Review of Reviews 1.I (January 1890): 15-20. Print. ---. From the Old World to the New; or, A Christmas Story of the World's Fair. London: Review of Reviews, 1892. Print. 
---. If Christ came to Chicago! A Plea for the Union of All Who Love in the Service of All Who Suffer. London: Review of Reviews, 1894. Print.

---. The Americanisation of the World; or, The Trend of the Twentieth Century. London: Review of Reviews, 1902. Print.

Stockton, Frank R. The Novels and Stories of Frank R. Stockton: The Great War Syndicate, etc. New York: Scribner, 1900. Print.

Strauss, Sylvia. “The American Myth in Britain.” South Atlantic Quarterly 72.I (1973): 66-81. Print.

“Tems Dyvirta." “London's Transformation. A Suggestive Sketch of Days to Come.” Knowledge and Scientific News n.s. 3 (January-February, 1906): 314, 339-342, 365-368. Print.

Tracy, Louis. The Final War. New York: G.P. Putnam, 1896. Print.

“Trygaeus." The United States of the World: An Utopian Essay Towards a Better Ordering of the Affairs of Men. London: Routledge, 1915. Print.

Waterloo, Stanley. Armageddon: A Story of Love, War, and Invention. Chicago and New York: Rand, McNally, 1898. Print.

Wells, H.G. Anticipations of the Reaction of Mechanical and Scientific Progress upon Human Life and Thought. London: Chapman and Hall, 1902. Print.

---. The Future in America: A Search after Realities. New York: Harper, 1906. Print.

---. The Outline of History. New York: Macmillan, 1920. Print.

---. The New America. The New World. New York: Macmillan, 1935. Print.

---. The Discovery of the Future. Ed. Patrick Parrinder. London: PNL P., 1989. Print.

Wilson, Angus. The Strange Ride of Rudyard Kipling. London: Granada, 1979. Print.

\section{NOTES}

i. Bulwer-Lytton elsewhere describes the Monroe Doctrine, explicitly referenced in The Coming Race, as an example of Americans "fondly colonizing Futurity" (Bulwer-Lytton 1864, p.167).

ii. One of the earliest novels to base its speculative society on the discovery of electricity was Another World (1873), set on another planet. Published under the pseudonym "Hermes," its author was Benjamin Lumley, the manager of a London theatre. These edited fragments give glimpses of how different kinds of electricity can revolutionize engineering.

iii. Other than the fact that he was British, the identity of Nunsowe Green remains unknown.

iv. In his preface Lach-Szyrma acknowledges a connection between his subject and BulwerLytton's but insists that he hasn't merely copied The Coming Race.

v. In 1890 Macnie changed the title of The Diothas to Looking Forward; or, The Diothas to emphasize its relation to Looking Backward, only to be accused of plagiarising from Bellamy's novel.

vi. Meda. A Tale of the Future is constructed as an edited account by a visitor to the year 5575 who falls into a "trance-like slumber." Apart from all the social changes, he learns that in 3334 union was achieved between Britain and the USA.

vii. American writers were also describing union between Britain and the USA, but after overt war. The narrator of Samuel Barton's The Battle of the Swash (1888) looks back from 1930 on the pointless destruction in war before an armistice gives the USA the whole of North America. Frank R. Stockton's The Great War Syndicate (1889) describes a war triggered by a fishing dispute. The eventual alliance between the countries transforms the future of the world: "after the formation 
of this Syndicate all the nations of the world began to teach English in their schools, and the Spirit of Civilization raised her head with a confident smile" (128). An Anglo-American alliance is signed without conflict in the journalist Stanley Waterloo's Armageddon (1898).

viii. In his introduction to The Outline of History Wells praised Reade for his "presentation of human history as one consistent process" (vii).

ix. In 1887 Greg published his two-volume History of the United States from the Foundation of Virginia to the Reconstruction of the Union.

x. At Huxley's suggestion, Fiske's first lecture series, “America's Place in History," was delivered at University College, London in 1879. The original title for Fiske's 1880 lecture series was "American Political Ideas Viewed from the Standpoint of Evolution" (Fiske xxiv).

xi. "The Doom of London" first appeared in The Idler (November 1892) and was collected in The Face and The Mask (1894). "Within an Ace of the End of the World" first appeared in McLure's Magazine for April 1900.

xii. If Christ Came to Chicago! (1894) and Satan's Invisible World Displayed (1897), discussed in Frankel, chapter 1.

xiii. Cf Frankel 58.

xiv. Robert Frankel argues judiciously that Stead is strategically vague about exactly what form an Anglo-American union should take, while at the same time insisting on its urgency (55-56).

xv. Quoted in: Frankel 68. Duncan Bell has argued that the cause of Anglo-Saxon unity was espoused by Stead, Carnegie and Wells through "expressions of utopian desire" for perpetual peace, triggered partly by the revolution in global communication brought about by the electric telegraph (12-16).

xvi. V. Besant's prospectus essay, “The Atlantic Union,” in Besant 1900.

xvii. Edgar Wallace's The Man Who Bought London (1915) similarly combines U.S. enterprise with British commercial activity. The American millionaire King Kerry establishes a financial trust in London because he alone possesses a vision of its future development, recording in his diary: "I see London extended to St. Albans on the north, New bury on the west, and Brighton on the south" (chapter 6).

xviii. For further commentary on Kipling's views on America, see Brogan.

xix. Without John Bull of course, this graphic anticipates the opening of the 1930s newsreel series The March of Time, where material and social progress is enacted as a stream of national figures march into the foreground of their imminent future.

xx. As Anticipations was coming out in serial form, it was being enthusiastically read by W.T. Stead, who played a key role in Wells's career by publishing a positive review of The Time Machine (Baylen 59).

xxi. Wells returned to this perception in The New America, The New World (1935), where found an even more striking acceleration in the tempo of American life. For a detailed analysis of his views on America, see Frankel, chapter 3.

xxii. Wells's sense of the cultural collapse brought about by the First World War that in 1922 he grimly warned: "in a little while, within my lifetime, New York City may stand even more gaunt, ruinous, empty and haunted than that stricken and terrible ruin, Petersburg" (Wells, 1922, chap. 1). His sense of how precarious the future had become clearly led him to choose as an example the one city where such a catastrophe seemed the least likely to happen.

xxiii. For further commentary on Huxley and America, see Meckier. 


\section{ABSTRACTS}

This article examines the ways in which British travelers to the USA at the end of the nineteenth and beginning of the twentieth centuries articulated their different perceptions of a nation which was emerging as a major imperial competitor. Characteristically these responses showed an ambivalent tension between respect for the growing commercial energy of the USA and a suspicion that it was posing an increasing threat to British national self-perception. Works examined here include those which attempt to yoke together the two nations in a common "Anglo-Saxon" destiny. The essay analyzes the expressive means used by writers to depict the USA as a culture of the future. The discussion includes famous figures like Rudyard Kipling and H.G. Wells, but also covers a range of turn-of-the-century speculative writers like the journalist W.T. Stead.

\section{INDEX}

Keywords: Edward Bulwer-Lytton, H.G. Wells, Rudyard Kipling, speculative fiction, travel writing, W.T. Stead

\section{AUTHOR}

DAVID SEED

Liverpool University 